\title{
NON-FINANCIAL REPORTING AS A CHALLENGE FOR THE CONTEMPORARY ACCOUNTING SYSTEM
}

\author{
HANNA CZAJA-CIESZYŃSKA
}

University of Szczecin, POLAND

e-mail: hanna.czaja@wzieu.pl

RECEIVED
ACCEPTED
JEL
CLASSIFICATION

KEYWORDS

ABSTRACT
12 May 2018

12 September 2018

M14, M21, M41, M48

non-finncial reporting, information system, accounting, sustainable development, CSR

The purpose of the article is to analyse and evaluate the degree of development of non-financial information reporting in Poland with particular consideration given to the role of accounting as a generator of information in this scope. The following considerations serve as an input to the debate and, as a result, the author formulated the research hypothesis as follows: non-financial information reporting in Poland is in its early phase of development. In order to evaluate the actual state, the author carried out the quantitative analysis of nonfinancial reports published by Polish economic units in the international register kept by the GRI as well as in the Polish Register of Reports kept by CRSinfo.

It appears from the study that obtaining comprehensive financial, non-financial, quantifiable and descriptive information requires moving away from treating accounting as a closed system and requires its development. In this context, social accounting, being a broader field in accounting, is getting more and more popular. Research methods applied in the study: literature studies, legal regulations analysis as well as the method of deductive reasoning and synthesis.

\section{Introduction}

Recent years have brought a dynamical increase in the importance of the idea of sustainable development and the related concept of the corporate social responsibility. As a result, the increasing expectations of investors, society and other groups of stakeholders forced companies to use a new form of communication with the environment, that is, publishing non-financial reports. 
The purpose of the article is to analyse and evaluate the degree of development of non-financial information reporting in Poland with particular consideration given to the role of accounting as a generator of information in this scope. The implementation of such a research task required the division of the article into three parts. The first one defines the term information and shows the place and role of accounting in the accounting information system of a company. The second part describes sources and premises of non-financial information reporting. The third part, in turn, includes the analysis of the Polish legal system in this scope and the quantitative evaluation of the degree of development of non-financial information reporting in Poland.

The following considerations serve as an input to the debate and, as a result, the author formulated the research hypothesis as follows: non-financial information reporting in Poland is in its early phase of development. For the purpose of this article, the author applied the following research methods: literature study, the analysis of legal regulations as well as the method of deductive reasoning and synthesis.

\section{The importance of the accounting information system}

Etymologically, the word "information" derives from the Latin informatio and means idea, explanation, notification (Drewniak, 2000, p. 79). In Poland one of the first authors, who in the seventies of the $20^{\text {th }}$ century defined the concept of information was J. Ratajewski. In his view, information is "a mutual relationship between at least two items (objects, organisms) consisting of a meaning (content) and a physical carrier (form), used for conveying signals of one entity (object, organism) to the other one (object, organism)" (Ratajewski, 1973, p. 8-9). In the context of conducting business activity, the term information means all the content of a message used actively by economic entities to make economic decisions (Oleński, 2010, p. 178). In this sense, information embraces all the paper and electronic databases, files, documents and oral instructions, which are generated, conveyed and collected in the enterprise's information system (Madej, 2002, p. 138).

The importance of the role of information for the efficient functioning of the enterprise cannot be overestimated. It is a significant strategic factor, frequently more important than capital or work (Kolbusz, 1999, $p$. 91). It contributes to the enterprise's development, predjudges the rationality and effectiveness of management and is used to communicate with the environment. In this context, apart from the amount of information, its quality also plays a significant role in business management. The term quality of information refers to a set of characteristics specifying its suitability for the protection of specific needs, resulting in particular from the objectives and activities imnplemented by the entity. The basic qualitative characteristics distinguishing useful information from the useless one are relevance, accuracy, timeliness, completeness, coherence, format, accessibility, compatibility, safety and verifiability (Miler, 1996).

The basic and most popular source of information meeting information needs of different groups of stakeholders is accounting. As A. Karmańska claims, accounting provides $70 \%$ of economic information essential for the enterprise's functioning (Karmańska, 2006, p. 274). The example highlighting the information nature of accounting is its definition from 1953 coined by the American Institute of Certified Public Accountants (AICPA), which states that accounting "is a process of identifying, measurement and communication of economic information with the aim to enable information users to make reasonable judgement and take a decision" (Helin, 2004, p. XXIX). A similar approach is visible in another definition, in the light of which "accounting is an information system, which identifies, informs and keeps a record of economic events of some business entity for interested users" (Weygandt, Kieso, Kimmel, 2002, p. 2). The place of accounting in the information system is depicted in Figure 1. 


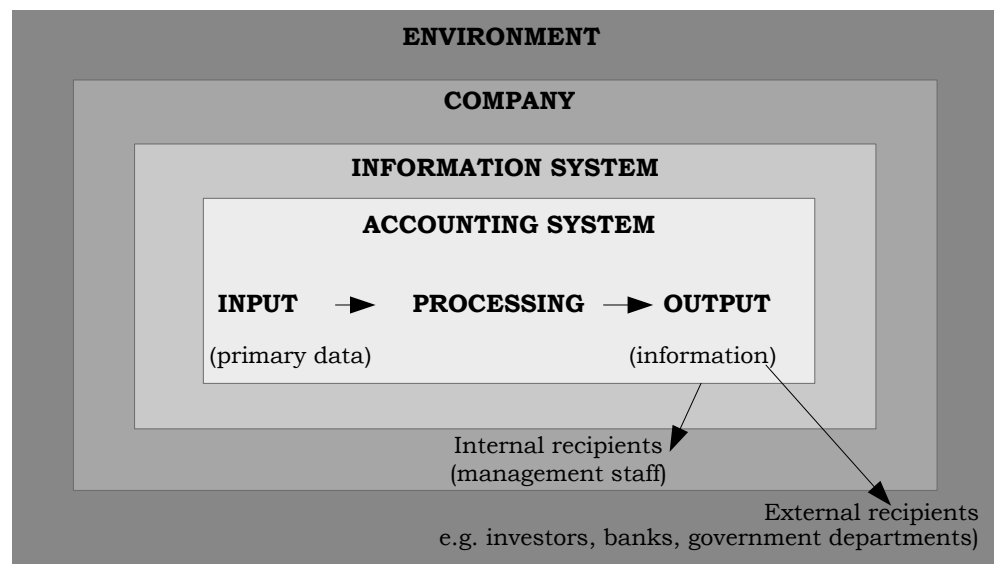

Figure 1. The place of accounting in the enterprise's information system

Source: own elaboration on the basis of Nowak (2007), p. 24.

The requirements of the recipients of information generated by accounting are higher and more diverse both in relation to the scope of disclosed information and the form of its presentation. Accounting has to be subject to amendments in order to meet these requirements. Over the last several decades, accounting has had to face, among others, the process of globalisation or the information age which has led to its intensive development. It is manifested in harmonization and standardization of accounting principles, increasing use of fair value in business assets valuation and in the necessity to report non-financial information.

\section{Sources and premises of disclosing non-financial information}

In the literature, the notion of "non-financial information" is interpreted in many different ways. There is no one common definition, which could be regarded as the one generally accepted and used (Sobczyk, 2017, pp. 395-401). According to J. Krasodomska, the notion of non-financial information embraces all the information (descriptive or numerical one, not necessarily expressed in cash) published (compulsorily or voluntarily) in the enterprise's annual report, apart from the financial statement and auditor's opinion and report (Krasodomska, 2014, p. 28).

In recent years, disclosing non-financial information has become a trend and it constitutes a response to increasing expectations of stakeholders in the scope of the multilevel informing about the company's operations. This information can be of a different nature and concerns various aspects of enterprise's functioning (economic, social and environmental), which is closely related with the development of the concept of sustainable development and the corporate social responsibility. The corporate social responsibility is a strategic and long-term approach, based on high ethical standards both in relation to employees and society and to environment. One of the broadest definitions of social responsibility was published in 2010 by the International Organization for Standardization ISO. According to ISO, CSR is "an organization's respoinsibility or the impacts of its decisions and activities on society and the environment, through transparent and ethical behaviour that (ISO 26000:2010):

- contributes to sustainable developmnent, including the health and welfare of the society,

- takes into account the expectations of stakeholders, 
- is in compliance with applicable law and consistent with international norms of behaviour,

- is integrated throughout the organization and practised in its relationships."

The areas of social responsibility according to ISO 26000 standard are depicted in Figure 2.
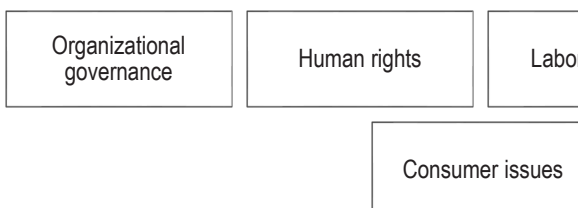
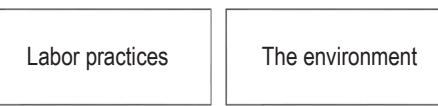

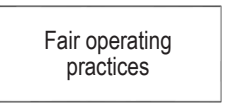

Figure 2. Areas of social responsibility according to ISO 26000 standard

Source: own elaboration on the basis of ISO 26000, p. 31, 32.

The main objective of disclosing non-financial information is, therefore, the reduction of information gap between stakeholders' information needs and information provided by traditional financial reporting (Dziawgo, 2016, p. 105). In this context, a broader field of accounting, that is, social accounting, is more and more often discussed. Social accounting involves "providing information about social and environmental effects of the company's activities focused on economic goals and exerted on individual groups of stakeholders and the society as a whole" (Gray, Owen, Maunders, 1987). One of the methods to communicate in this scope is to publish non-financial information in the form of the so called social reports, sustainable development reports, CSR reports, business or corporate reports. These constitute the form of dialogue between the company and the environment and this information should be complete, reliable, useful and comparable in each reporting period (Fijałkowska, 2012, p. 148).

Disclosing non-financial information may bring the company a number of benefits, mainly due to the company image. The most important reasons for providing non-financial reports by companies are the following (Kaputa, 2013, p. 116):

- transparency and the willingness to show the company's engagement in different social and ecological initiatives,

- improvement of the company's reputation and credibility for investors,

- demonstration of the ability to participate in competitive markets,

- sustainable planning of the company's activities,

- support in solving current problems and reacting to them,

- creation of greater awareness of the CSR issue and facilitated implementation of sustainable development.

In conclusion, it is important to highlight that non-financial reporting is applicable to all public, private and non-profit organizations, regardless of their size or location. It can be compulsory or voluntary. Despite the fact that it concerns mainly large enterprises, more and more frequently non-financial reports are published also in other economic sectors, e.g. in small and medium-sized enterprises and in non-governmental organizations.

\section{Development of non-financial reporting in Poland}

The basic legal act regulating the accounting system in Poland is the Accounting Act of 29 September 1994 (Journal of Laws 2018 item 395). Until 2017, there was practically no reporting of non-financial information in Polish 
legislation and it was limited to information disclosure in the report on the operations (relevant information about the company's assets and financial position, including evaluation of results as well as indication of risk factors and description of threats). It was only the amendment to the Accounting Act of 15 December 2016, which transposed the EU directive on disclosure of non-financial and diversity information to Polish law, that introduced a number of relevant changes in this scope (Directive 2014/95/EU). Firstly, non-financial information reporting became compulsory for the so called public trust institutions. Public trust institutions are entities, in which the average annual employment is over 500 people for two consecutive years and one of the two financial criteria is exceeded - the balance sheet total over 85 million PLN or net revenue from sales of goods and products over 170 million PLN (The Accounting Act 2018, art. 49b, item 1). The obligation of reporting non-financial information refers to financial statements for the financial year 2017. Secondly, reporting of extended non-financial information can be in the form of a statement, as a separate part of the company's operations report, or in the form of a separate non-financial report. In both cases it has to include at least (The Accounting Act 2018, art. 49b, item 2):

- a concise description of the company's business model,

- key non-financial performance indicators related to the company's activities,

- description of the policies adopted by the company in relation to social and employee issues, natural environment, human rights respect as well as combating corruption and description of results of these practices,

- description of due dilligence procedures,

- description of relevant risks that may adversely affect the company's activities, including description of the management of those risks.

Thridly, the legislator did not impose the applicable legal framework being the basis of non-financial reporting. This means that the entities making an effort in this scope may rely on the national, the EU or international policy framework. Examples include, among others, the GRI (Global Reporting Initiative) standards, the International Integrated Reporting Framework (IR), the UN Global Compact Initiative, guidelines of the Organization for Economic Cooperation and Development (OECD) for multinational enterprises or the abovementioned ISO 2600 standard of the International Organization for Standardization.

The most popular reporting standards for responsible business and sustainable development both in Poland and in the world are the GRI standards. In accordance with the situation as at 1 March 2018, non-financial reporting has been adopted so far by over 12 thousand entities in the world, which published 46,5 thousand reports, including $63 \%$ of reports prepared in accordance with the GRI standards (http://database.globalreporting.org). Quantitative summary of non-financial reports published by Polish economic entities is presented in Table 1, which shows the number of non-financial reports registered in the International Register kept by the GRI and in the Polish Register of Reports kept by CRSinfo.

Until the end of 2017, 286 reports were published in the international base kept by the GRI, whereas 370 reports in the national Register of Reports. The presented figures clearly indicate that reporting of non-financial information in Poland is in its early phase of development. It is even more visible when compared with the results in other European countries, such as Greece - 437 reports, the Netherlands - 1175 reports, Germany - 1439 reports or Spain - 2133 reports. The number of non-financial reports published in the selected European countries is presented in Figure 3. 
Table 1. The number of non-financial reports registered in Poland until 2017

\begin{tabular}{ccc}
\hline \multirow{2}{*}{ Year of publication } & \multicolumn{2}{c}{ The number of non-financial reports registered in Poland } \\
\cline { 2 - 3 } & The GRI Register & The Register of Reports \\
\hline until 2003 & 0 & 0 \\
2004 & 1 & 0 \\
2005 & 0 & 1 \\
2006 & 1 & 4 \\
2007 & 5 & 8 \\
2008 & 6 & 11 \\
2009 & 10 & 14 \\
2010 & 14 & 25 \\
2011 & 23 & 34 \\
2012 & 29 & 37 \\
2013 & 44 & 48 \\
2014 & 36 & 40 \\
2015 & 44 & 55 \\
2016 & 43 & 43 \\
2017 & 29 & 50 \\
\hline Total & 286 & 370 \\
\hline
\end{tabular}

Source: own elaboration based on http://database.globalreporting.org and www.rejestrraportow.pl (1.03.2018).

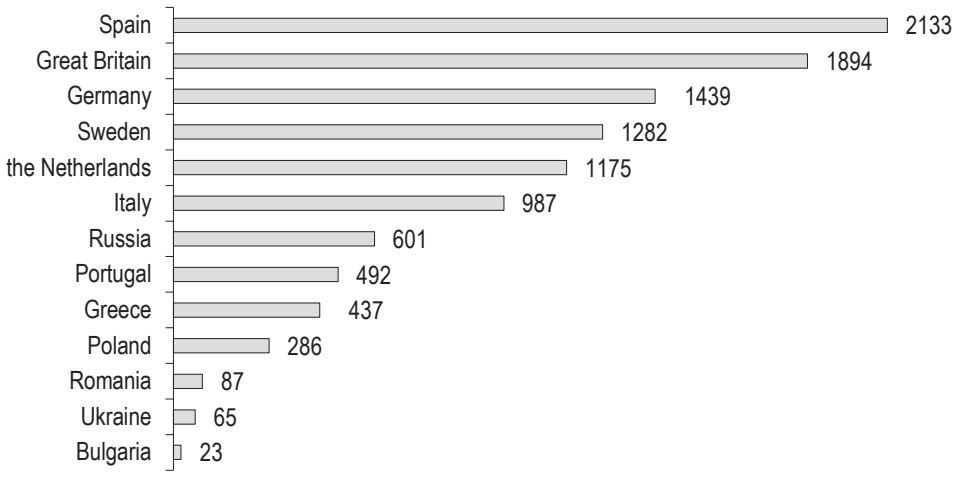

Figure 3. The number of non-financial reports registered in the GRI base until 2017 in the selected European countries

Source: own elaboration based on http://database.globalreporting.org (1.03.2018).

However, it should be underlined that Poland is now in a period of transition as all non-financial reports have been published voluntarily so far. The statutory obligation to disclose extended non-financial information for public trust institutions introduced in 2017 will influence the number of published reports only at the end of 2018. It is estiumated that in 2018 obligatory non-financial reports will be published by about 300 enterprises. 


\section{Conclusions}

The growing importance of the concept of sustainable development imposed the necessity to develop contemporary reporting methods by the accounting system. Enterprises, which want to increase their value in the eyes of their stakeholders, cannot concentrate solely on presenting financial information. It is, therefore, publishing non-financial information that constitutes a true expression of concern for the relationships with the environment. This means that accounting, in its current form, is no longer able to meet the requirements of its users. In this context, social accounting, being a broader field of accounting, is getting more and more popular. Obtaining comprehensive financial, non-financial, quantifiable and descriptive information requires moving away from the traditional financial reporting into the multidimensional non-financial one.

\section{References}

Drewniak, R. (2000). Rola systemu informacyjnego w procesie podejmowania decyzji w przedsiębiorstwie. Acta Universitatis Nicolai Copernici, Ekonomia, XXX (341).

Dziawgo, D. (2016). Znaczenie raportowania pozafinansowego w opinii inwestorów indywidualnych. Scientific Papers of Wrocław University of Economics, 436.

Directive 2014/95/EU of the European Parliament and of the Countil of 22 October 2014 amending Directive 2013/34/EU as regards disclosure of non-financial and diversity information by certain large undertakings and groups.

Fijałkowska, J. (2012). Społeczna odpowiedzialność wyzwaniem dla rachunkowości. Entrepreneurship and Management, XIII, 1.

Gray, R., Owen, D., Maunders, K. (1987). Corporate Social Reporting - Accounting \&Accountability. Prentice - Hall, UK.

Helin, A. (2004). Ustawa o rachunkowości. Podatkowe komentarze praktyczne. Warszawa: C.H. Beck.

http://database.globalreporting.org (1.03.2018).

International Organization for Standarization, ISO 26000:2010 Guidelines concerning social responsibility (2012).Warsaw: Polish Committee for Standardization.

Kaputa, J. (2013). Raportowanie zrównoważonego rozwoju jako wyzwanie dla przedsiębiorstw XXI wieku. Journal of Management and Finance, 1 (11), part 2.

Karmańska, A. (2006). Informacyjne atrybuty rachunkowości finansowej. In: P. Wachowiak (ed.), Funkcjonowanie przedsiębiorstwa w gospodarce rynkowej. Warszawa: The Accountants Association in Poland.

Kolbusz, E. (1999). Strategiczne zarządzanie informacją. Strategia systemów informacyjnych. Conference materials of the University of Economics in Cracow, Kraków.

Krasodomska, J. (2014). Informacje niefinansowe w sprawozdawczości spółek. Kraków: Uniwersytet Ekonomiczny w Krakowie.

Madej, J. (2002). Polityka bezpieczeństwa i system ochrony informacji w przedsiębiorstwie. Zeszyty Naukowe Akademii Ekonomicznej w Krakowie, 604.

Miller, H. (1996). The Multiple Dimensions of Information Quality. Information Systems Management, 2 (13).

Nowak, E. (2007). Rachunkowość. Kurs podstawowy. Warszawa: Polskie Wydawnictwo Ekonomiczne.

Oleński, J.(2001). Ekonomika informacji. Warszawa: Polskie Wydawnictwo Ekonomiczne.

Ratajewski, J. (1973). Wstęp do informacji naukowej. Katowice: University of Silesia.

Sobczyk, M. (2017). Zakres pojęciowy terminu "informacja niefinansowa” jako źródło zróżnicowania ujawnień niefinansowych przedsiębiorstw. Finanse, Rynki Finansowe, Ubezpieczenia, 4 (88/1), 395-401.

The Act of 29 September 1994 on Accounting, Journal of Laws 2018, item 395.

Weygandt, J., Kieso, L.E., Kimmel, D.D. (2002). Accounting Principles. New York: John Wiley and Sons.

www.rejestrraportow.pl (1.03.2018).

Cite this article aS: Czaja-Cieszyńska, H. (2018). Non-financial reporting as a challenge for the contemporary accounting system. European Journal of Service Management, 3 (27/1), 31-37. DOI: 10.18276/ejsm.2018.27/1-04. 